\title{
Correction \\ Correction: Lehtonen et al. The Potentials of Tangible Technologies for Learning Linear Equations. Multimodal Technol. Interact. 2020, 4, 77
}

\author{
Daranee Lehtonen $^{1, *(\mathbb{D})}$, Lucas Machado ${ }^{2,3}\left(\mathbb{D}\right.$, Jorma Joutsenlahti ${ }^{1}$ and Päivi Perkkilä ${ }^{4}$ \\ 1 Faculty of Education and Culture, Tampere University, Åkerlundinkatu 5, P.O. Box 700, \\ 33014 Tampere, Finland; jorma.joutsenlahti@tuni.fi \\ 2 Faculty of Information Technology and Communication Sciences, Tampere University, \\ Kanslerinrinne 1 Pinni B, P.O. Box 300, 33014 Tampere, Finland; lucas@demola.net \\ 3 Demola Global, Åkerlundinkatu 8, 33100 Tampere, Finland \\ 4 Faculty of Education and Psychology, University of Jyväskylä, P.O. Box 35, 40014 Jyväskylä, Finland; \\ paivi.m.perkkila@jyu.fi \\ * Correspondence: daranee.lehtonen@tuni.fi
}

check for

updates

Citation: Lehtonen, D.; Machado, L.; Joutsenlahti, J.; Perkkilä, P. Correction: Lehtonen et al. The Potentials of Tangible Technologies for Learning Linear Equations. Multimodal Technol. Interact. 2020, 4, 77. Multimodal Technol. Interact. 2022, 6, 5. https://doi.org/10.3390/ mti6010005

Received: 6 January 2022 Accepted: 6 January 2022 Published: 10 January 2022

Publisher's Note: MDPI stays neutral with regard to jurisdictional claims in published maps and institutional affiliations.

Copyright: (C) 2022 by the authors. Licensee MDPI, Basel, Switzerland. This article is an open access article distributed under the terms and conditions of the Creative Commons Attribution (CC BY) license (https:// creativecommons.org/licenses/by/ $4.0 /)$.
In the original publication, there was a mistake in Table 3 as published.

We, the authors, wish to make the following correction to our paper [1]. There is a typing error in the last cell of Table 3 regarding the total $n(\%)$ value of verbalisation and physical actions 105 (6.6). The corrected Table 3 appears below. The authors apologise for any inconvenience caused and state that the scientific conclusions are unaffected. The original publication has also been updated.

Table 3. Observed frequencies and percentages of peer communication episodes regarding directions and types by instructional condition.

\begin{tabular}{lccc}
\hline \multirow{2}{*}{ Communication } & Paper-and-Pencil & X-is & Total \\
\cline { 2 - 4 } & $\boldsymbol{n ( \% )}$ & $\boldsymbol{n ( \% )}$ & $\boldsymbol{n} \mathbf{( \% )}$ \\
\hline Directions $(\boldsymbol{N}=\mathbf{2 8 7})$ & & & \\
One-way & $51(17.8)$ & $60(20.9)$ & $111(38.7)$ \\
Two-way & $34(11.8)$ & $142(49.5)$ & $176(61.3)$ \\
\hline Types $(\boldsymbol{N}=\mathbf{2 8 7})$ & & & \\
Verbalisation & $62(21.6)$ & $97(33.8)$ & $159(55.4)$ \\
Physical actions & $7(2.4)$ & $16(5.6)$ & $23(8.0)$ \\
Verbalisation and physical actions & $16(5.6)$ & $89(31.0)$ & $105(36.6)$ \\
\hline
\end{tabular}

\section{Reference}

1. Lehtonen, D.; Machado, L.; Joutsenlahti, J.; Perkkilä, P. The Potentials of Tangible Technologies for Learning Linear Equations. Multimodal Technol. Interact. 2020, 4, 77. [CrossRef] 